\title{
Magnae Moraviae Fontes Historici. I: Annales et chronice / Prameny k dějinám Velké Moravy. I: Letopisy a kroniky, ed. Dagmar Bartoňková, David Kalhous, Jiří K. Kroupa, Zdeněk Měřínský, Anna Žáková, Koniasch Latin Press, Praha 2019, ss. XXII + 506, III wydanie zrewidowane i rozszerzone
}

W 2019 r. wspólnymi siłami zespołu: historyków, historyka sztuki i latynistów światło dzienne ujrzało trzecie zrewidowane i rozszerzone wydanie pierwszego tomu Magnae Moraviae Fontes Historici ${ }^{1}$. To niezwykle użyteczne wydawnictwo źródłowe charakteryzowało się tym - i nadal tak czyni - że oddaje czytelnikowi do dyspozycji wydanie krytyczne tekstu źródłowego poprzedzone wprowadzeniem naukowym wraz z podaniem literatury przedmiotu dotyczącego danego źródła. Dalej umieszczono przedrukowane źródło z edycji krytycznej w lewej kolumnie (lub stronie), a w prawej kolumnie (lub stronie) umieszczono czeskie tłumaczenie przekazu obecnego po prawej stronie w formule tzw. lustrzanego wydania. Opublikowane teksty opatrzono aparatem krytycznym, podającym zarówno odmianki tekstowe z różnych rękopisów, jak i przypisy naukowe komentujące dany tekst i przytaczające literaturę naukową. W pierwszym tomie wydano w ten sposób urywki z kronik oraz roczników dotyczących Wielkich Moraw z okresu średniowiecza. Pierwsze wydanie pierwszego tomu tej serii światło dzienne ujrzało ponad 50 lat temu w 1966 r. przede wszystkim zasługą Lubomíra Havlíka. Pierwotnie serię Magnae Moraviae Fontes Historici podzielono na cztery zasadnicze części: I. roczniki i kroniki, II. dokumenty

1 Poprzednie wydania to: Magnae Moraviae fontes historici Prameny k dějinám Velké Moravy. I., wyd. Dagmar Bartoňková i in., Praga 1966; Magnae Moraviae fontes historici Prameny k dějinám Velké Moravy. I., wyd. Dagmar Bartoňková i in., Praga 2008. 
i przywileje, III. utwory hagiograficzne, IV. teksty prawne. Najnowsze trzecie wydanie nawiązuje do pierwszego wydania z 1966 r. i nieco dystansuje się względem drugiego wydania z 2008 r. O ile w tym drugim wydaniu zachowano pierwotne komentarze Havlíka, o tyle w edycji z 2019 r. zdecydowano się znacząco poszerzyć je o najnowsze dokonania na polu historii i archeologii. Ponadto wydawcy zdecydowali się na to, aby wykorzystać nowsze dostępne wydania krytyczne tekstów, które ujrzały światło dzienne od lat sześćdziesiątych XX w. Szczególnie dotyczy to tekstów zapisanych w języku górno-wysoko-niemieckim i to zarówno pierwotnie $\mathrm{w}$ nim spisanych, jak i tłumaczonych na niego z łaciny i staroczeskiego. Wydawcy, podając tekst źródeł, zdecydowali się na przytaczanie wydawanych tekstów za opublikowanymi już wydaniami krytycznymi dostępnymi na rynku. Tłumaczenia na czeski sporządzili przede wszystkim Dagmar Bartoňková, często we współpracy z Jaroslavem Ludvíkovskim. Pewną grupę źródeł przełożyli: Lubomír Havlík, Radoslav Večerka, Zdeněk Masař́k i Vlastimil Brom. Na potrzeby recenzowanego wydania D. Bartoňkowa i Anna Žákova dokonały rewizji wydanych tekstów i ich tłumaczeń, z wykorzystaniem dostępnych najnowszych wydań krytycznych tekstów. Rzeczowy aparat przypisów opiera się na pierwotnym, zbudowanym przez Lubomíra Havlíka, jego zaś autorami są Zdeněk Měŕnský (który nie dożył końca prac, zm. 2016 r.) we współpracy z Davidem Kalhousem, Jiř́m K. Kroupou i A. Žákovą. Ponadto wydawcy odpowiedzialni za przypisy uściślili podawane informacje i usunęli niejasności obecne wcześniej².

Zawartość tomu prezentuje się następująco: spis treści (s. vii-viii), Praefatio (s. xi), Úvodem k. I. svazku (s. xiii-xv), Abbreviationes (s. xvi), Conspectus fontium in forma abbreviata redditorum (s. xvii-xviii), Tabulae geographicae (s. xix-xxii), dalej zaś następuje część właściwa, tj. Annales et chronicae (s. 1-421). Wśród bardzo licznych fragmentów z różnych średniowiecznych przekazów, których nie sposób tu wszystkich przytoczyć, odnotujmy tylko przykładowo: fragmenty frankijskich i „niemieckich” kronik i roczników (np. Annales regni Francorum, Annales Mettenses priores, Annales Xantenses, Annales Fuldenses, Annales Sancti Emmerammi Ratisponensis minores, Widukindi monachi Corbeiensis Rerum gestarum Saxonicarum libri tres), ustępy z dzieł pisarzy żyjących poza Czechami i Rzeszą (Mariani Scotti Chronicon, Chronicon Hungarico-Polonicum, Sigeberti Gemblacensis Chronica, Galli Anonymi Chronicon, Povest'vremennych let, O preloženii knig), jak i wiele późnośredniowiecz-

2 Recenzja Miroslava Lysego, Magnae Moraviae Fontes Historici I Annales et chronice Prameny $k$ dèjinám velké moravy I Letopisy a kroniky, Historický časopis nr 68 (2020), nr 5, s. $889-891$. 
nych przekazów uwzględniajacych informacje o Wielkich Morawach (Martini Oppaviensis Chronicon pontificum et imperatorum, Kronika tak řečeného Dalimila, Chronici Hungarici compositio saeculi XIV., Chronicon Posoniense, Aeneae Silvii Piccolomini Historia Bohemica). W partii końcowej znajdujemy: Conspectus fontium (s. 423-430), Commentarii et disputationes (s. 431-443), Index (444-496), Index historicorum, editorum et auctorum contemporaneorum (s. 497-504).

To bogate wydanie źródeł ukazuje, jak wiele informacji o Wielkich Morawach odnotowali różni autorzy na przestrzeni dziejów. Obszerne i bogate przypisy, niezwykle przydatne i cenne wprowadzenia wraz z podaniem licznej literatury pozwalają na uzyskanie cennej, tak dawnej, jak przede wszystkim aktualnej wiedzy związanej z konkretnym źródłem, pozwalając odbiorcom na dostęp do podstawowych informacji. Niezwykle cenną pomocą pozostaje ponadto indeks osób, miejsc i tekstów źródłowych. Polscy czytelnicy mogą skorzystać z tej publikacji przede wszystkim w trzech zasadniczych przypadkach. 1. Przy badaniu historii Wielkich Moraw (w tym i ich relacji zagranicznych). 2. Przy badaniu najstarszych losów Słowian w Europie Środkowej, jak też szerzej dziejów tego regionu. 3. Do pogłębienia zainteresowań tematyką i tradycją wielkomorawską wśród polskich czy związanych z Polską autorów roczników i kronik.

Podsumowując, należy stwierdzić, że mamy tu do czynienia z bardzo cenną publikacją zarówno pod względem merytorycznym, jak i wydawniczym, natomiast czytelnicy zainteresowani losami Wielkich Moraw znajdą tu niezbędną podstawę źródłową w postaci roczników i kronik, pozwalającą lepiej zrozumieć nie tylko fenomen tego tworu politycznego, ale też jego recepcję, zarówno we współczesnej, jak i w późniejszej tradycji dziejopisarskiej.

Dr Wojciech Jasiński

Wydział Historii, Uniwersytet im. Adama Mickiewicza w Poznaniu

ul. Uniwersytetu Poznańskiego 7

61-614 Poznań

e-mail:wojciechjasinski@amu.edu.pl 